\title{
EDUKASI STRATEGI KOPING SEBAGAI UPAYA DALAM MENURUNKAN TINGKAT STRES PADA SISWA SMKN 4 GARUT SELAMA PANDEMI COVID-19
}

\author{
Theresia Eriyani ${ }^{1}$, Iwan Shalahuddin ${ }^{2 *}$, Indra Maulana ${ }^{3}$ \\ ${ }^{1,2,3}$ Fakultas Keperawatan Universitas Padjadjaran Kampus Garut \\ Email Koresponden: shalahuddin@unpad.ac.id
}

\begin{abstract}
ABSTRAK
Menanggapi bahayanya virus Covid-19, pemerintah Indonesia mengeluarkan beberapan peraturan mengenai protokol kesehatan, salah satunya ialah protokol mennjaga jarak atau social distancing yang kemudian ditindaklanjuti dengan kebijakan PSBB yang justru menyebabkan terganggunya kesehatan mental, terutama pada remaja sekolah yang diisukan mengalami stress dengan adanya sistem PJJ. Pada penkes ini kami memberikan edukasi pada siswa/i SMKN 4 Garut mengenai pengelolaan stres dengan strategi koping. Ruang lingkup dalam kegiatan Penkes ini ialah siswa dan siswi SMKN 4 Garut. Tujuan: Kegiatan penkes ini bertujuan untuk meningkatkan pengetahuan siswa dan siswi SMKN 4 Garut dalam melakukan pengelolaan stress dengan strategi koping selama masa pandemi covid-19. Metode: Kegiatan penkes ini mengintegrasikan konsep teori HBM. Penkes ini menggunakan metode lecture atau ceramah dengan menggunakan media powerpoint yang dilaksanakan secara daring menggunakan platform Zoom Meeting. Hasil yang ditemukan dari kegiatan penkes ini ialah persentase pengetahuan peserta mengenai stress dan strategi koping meningkat setelah diberikan materi yang dapat dilihat dari hasil post test sebagian besar peserta penkes. Simpulan yang dapat diambil dari kegiatan penkes ini ialah, terdapat peningkatan pengetahuan pada siswa dan siswi SMKN 4 Garut mengenai stress dan pengelolaan stress dengan strategi koping, setelah peserta diberikan pretest sebelum pemberian materi dan diberikan post test setelah pemberian materi.
\end{abstract}

Kata Kunci: Health Belief Model, Pandemi Covid-19, Strategi koping, Stres

\begin{abstract}
Responding to the dangers of the Covid-19 virus, the Indonesian government issued several regulations regarding health protocols, one of which is the social distancing protocol which is then followed up with the PSBB policy which actually causes mental health disruption, especially for school teenagers who are rumored to be experiencing stress with the PJJ system. . At this health center we provide education to students of SMKN 4 Garut about stress management with coping strategies. The scope of this Penkes activity is students and students of SMKN 4 Garut. Purpose: This Health Center activity aims to increase the knowledge of students and students of SMKN 4 Garut in managing stress with coping strategies during the Covid-19 pandemic. Methods: This health center activity integrates the HBM theory concept. This Health Center uses the lecture method or lectures using powerpoint media which are held online using the Zoom Meeting platform. The results found from this Health
\end{abstract}


Center activity were that the percentage of participants' knowledge about stress and coping strategies increased after being given the material which can be seen from the post test results of most of the Health Center participants. The conclusions that can be taken from this Health Center activity are, there is an increase in knowledge of students of SMKN 4 Garut about stress and stress management with coping strategies, after participants are given a pretest before giving material and given a post test after giving the material.

Keywords: Health Belief Model, Covid-19 Pandemic, Coping Strategy, Stress

\section{PENDAHULUAN}

Pernyataan dari seorang narasumber pada salah satu seminar kesehatan mengenai Pandemi Covid-19, pada akhir tahun 2019 lalu, dunia sempat diguncangkan dengan adanya kabar kemunculan virus covid-19 yang di Wuhan China. Hingga akhirnya pada awal tahun 2020, tepatnya pada bulan Februari virus Covid-19 mulai memasuki Indonesia. Virus Covid-19 merupakan jenis virus baru yang mengganggu sistem pernapasan dengan menginfeksi alveolus, tempat bersirkulasinya $\mathrm{O}_{2}$ dan $\mathrm{CO}_{2}$ di dalam tubuh. Virus ini sangat berbahaya, karena gejala yang terjadi pada individu yang terinfeksi tidak dapat dilihat dengan adanya perubahan fisik, sedangkan individu yang telah terinfeksi dapat menularkan virus ini melalui droplet yang dapat terpapar pada individu lainnya ketika berbicara, bersin, dan batuk (Shalahuddin, I., et al, 2021).

Mengetahui urgensi tersebut, pemerintah Indonesia menetapkan beberapa protokol kesehatan, salah satunya yaitu social distancing, seperti yang telah dituliskan dan dijelaskan pada KMK RI No. HK.01.07/MENKES/382/2020 pada Bab 1 poin 1.c. Kemudian, pemerintah menindaklanjuti protokol kesehatan tersebut dengan dilaksanakannya PSBB (Pembatas Sosial Bersakala Besar), sebagaimana yang telah dituliskan dan dijelaskan pada Permenkes No. 9 Tahun 2020 pada bab 1 pasal 1 ayat 1. Dilaksanakannya PSBB, akhirnya memunculkan istilah baru yaitu WFO (Work From Home) bagi para pekerja atau PJJ (Pembelajaran Jarak Jauh) bagi para pelajar. Namun, dalam pelaksanaannya, strategi pencegahan ini justru ikut menimbulkan masalah baru, yaitu gangguan pada kesehatan mental masyarakat Indonesia yang dapat menyebabkan daya imunitasnya menurun dan membuat individu tersebut semakin rentan terpapar virus Covid-19. Gangguan kesehatan mental yang terjadi selama pandemi Covid19 ini, dapat terjadi di berbagai kalangan usia, termasuk salah satunya ialah remaja (Ananda, S. S. D., \& Apsari, N. C, 2020; Fitria, L., \& Ifdil, I, 2020).

Hal ini kemungkinan besar disebabkan karena kurangnya informasi yang diperoleh remaja terkait dengan pandemi covid-19 ini (Purwanto et al., 2020). Remaja berpikiran bahwa virus corona sangat berbahaya (Zaharah, Kirilova, \& Windarti, 2020), yang apabila seseorang terinfeksi virus ini sulit untuk pulih (Putri, 2020), dan meningkatkan kasus kematian. Beberapa faktor yang menyebabkan anxiety pada masa pandemic COVID19 adalah kurangnya informasi mengenai kondisi ini, pemberitaan yang terlalu heboh di media masa ataupun media social (Aulia, 2018) dan kurangnya minat baca remaja untuk membaca literasi terkait dengan penyebaran dan mengantisipasi penularan corona virus.

Menanggapi hal ini, diperlukan peran dan tindakan dari berbagai tenaga kesehatan, salah satunya ialah perawat. Dalam Permenkes RI No. 26 tahun 2019 Tentang Peraturan Pelaksanaan UU No. 38 Tahun 2014 pada pasal 16 poin c, 
dijelaskan mengenai tugas dari perawat sebagai penyuluh dan konselor bagi klien atau pasien dalam hal ini ialah remaja atau pelajar SMA.

Promosi kesehatan merupakan proses perubahan perilaku atau proses belajar secara terencana pada diri individu, kelompok atau masyarakat dalam meningkatkan kemampuan (pengetahuan-sikap dan keterampilan) untuk mencapai derajat hidup sehat yang optimal. Tujuan promosi kesehatan secara umum adalah merubah perilaku dibidang kesehatan dan secara khusus membuat klien/masyarakat menyadari nilai kesehatan, mandiri mecapai hidup sehat dan memanfaatkan pelayanan kesehatan secara tepat guna (Susilowati, D, 2016).

Komite Bersama Pendidikan Kesehatan dan Promosi Terminologi Tahun 2001 mendefinisikan Pendidikan Kesehatan sebagai "kombinasi dari pengalaman belajar yang direncanakan berdasarkan teori suara yang memberikan individu, kelompok, dan masyarakat kesempatan untuk memperoleh informasi dan keterampilan yang dibutuhkan untuk membuat keputusan kesehatan yang berkualitas." Dalam mencapai tujuan tersebut seorang individu, kelompok atau masyarakat tidak terlepas dari kegiatan belajar (Azmi, 2013). Jadi, tujuan pendidikan kesehatan adalah untuk memperoleh pengetahuan dan pemahaman pentingnya kesehatan untuk tercapainya perilaku kesehatan sehingga dapat meningkatkan derajat kesehatan fisik, mental dan sosial, sehingga produktif secara ekonomi maupun sosial (Joesafira, 2012)

\section{MASALAH}

Menurut WHO (2019) dalam buku Mental Health During Covid-19 Pandemic, stress yang muncul selama masa pandemi COVID-19 bisa berupa rasa stress mengenai kesehatan diri dan kesehatan orang terdekatnya, pola tidur/pola makan berubah, sulit berkonsentrasi, hingga menggunakan obat-obatan/ narkoba. Kondisi psikologis para remaja yang cenderung masih rentan dan mudah terganggu, makin diperparah dengan kondisi di lingkungan sekitarnya yang tidak mendukung mereka melakukan aktivitas seperti biasanya. Situasi pandemi seperti sekarang juga mengharuskan para remaja untuk bisa bertindak sesuai dengan kondisi dan aturan yang ada dan mereka tidak bebas melakukan sesuatu yang menjadi kebiasaan mereka untuk dilakukan di luar rumah.

Pada penelitian Sherien dan Nurliana (2020), menjelaskan bahwa, salah satu faktor yang menyebabkan terjadinya stress pada remaja selama pandemic covid-19 ini ialah akibat kesulitan mereka dalam mengikuti sistem Pembelajaran Jarak Jauh. Dalam penelitiannya, disebutkan anggapan para pelajar, bahwa dilaksanakannya sistem PJJ ini, membuat sistem pembelajaran menjadi kurang efektif. Dalam penelitiannya, peneliti juga menambahkan hasil survei yang dilakukan KPAl, yaitu sebanyak 79,9\% pelajar mengatakan, bahwa sistem daring ini membuat interaksi, antara guru dan murid, berkurang dan guru hanya memberikan tugas yang berat saja, sehingga pelajar mengalami peningkatan stress (Ananda \& Apsari, 2020). Dengan adanya pandemi covid-19 ini, semua pembelajaran dituntut untuk dilakukan secara digital dengan paradigma yang membosankan sehubungan dengan metode pembelajara yang relative monoton dan semakin memicu adanya perasaan tertekan pada siswa SMKN 4 Garut selama sistem PJJ dilaksankan.

Secara biologis, saat seseorang mengalami stress yang dipengaruhi oleh suatu stressor, kemudian impuls diterima oleh reseptor yang akan mengirim pesan ke otak. Stressor tersebut kemudian diterima oleh otak, khususnya bagian depan yang mengakibatkan bekerjanya kelenjar di dalam organ tubuh dan otak. 
Organ tubuh dan otak saling bekerja sama untuk menerjemahkan proses stress yang pada akhirnya akan mempengaruhi system fungsi kerja tubuh.

Saat seseorang mengalami stress, biasanya mereka akan sulit untuk focus, mudah marah, tidak bisa duduk dengan tenang, sulit untuk tidur, merasa sedih atau bersalah, merasa cemas, mudah menangis, mudah lelah, mengalami perubahan pada pola dan nafsu makan, serta mulai berpikir tentang hal-hal buruk yang sudah terjadi di masa lalu atau yang akan terjadi di masa depan.

Berdasarkan latar belakang di atas, untuk meminimalisasi terjadinya dan dampaknya, perlu diberikan arahan dan pendidikan ilmu pengetahuan yang berkelanjutan, salah satunya dengan memberikan Pendidikan kesehatan. Oleh karena itu, sebagai strategi untuk menindaklanjuti permasalahan tersebut, kami memberikan pendidikan kesehatan pada seluruh pelajar SMK 4 Garut mengenai strategi pengelolaan stress yang tepat melalui strategi koping sebagai suatu upaya dalam menurunkan tingkat stress pada remaja khususnya pelajar selama masa pandemic Covid-19.

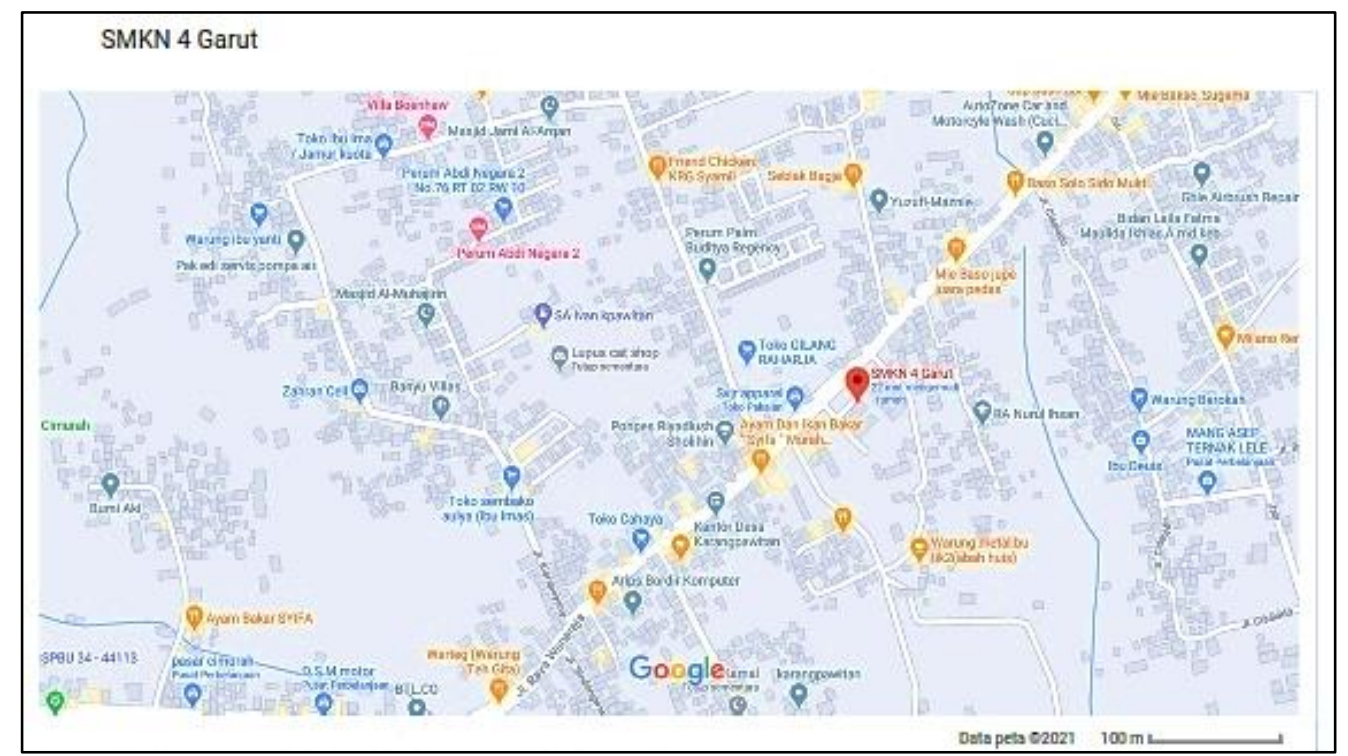

Gambar 1. Peta Lokasi SMKN 4 Garut

\section{METODE.}

Dalam pendidikan dan promosi kesehatan ini, kami mengintegrasikan teori Health Belief model dalam menyampaikan materinya. Konsep teori Health Belief Model (HBM) bertujuan untuk memahami kegagalan orang dalam mengadopsi strategi pencegahan penyakit atau tes skrining untuk deteksi dini penyakit. Selanjutnya, penggunaan atau aplikasi dai konsep teori ini adalah untuk respons pasien terhadap gejala dan kepatuhan terhadap perawatan medis. Kemudian, dari konsep teori HBM ini didapatkan, bahwa keyakinan seseorang pada ancaman pribadi dari suatu penyakit atau penyakit bersama dengan keyakinan seseorang pada keefektifan perilaku atau tindakan kesehatan yang direkomendasikan akan memprediksi kemungkinan orang tersebut akan mengadopsi perilaku tersebut (LaMorte, Behavioral Change Models, 2019).

Sesuai dengan tujuan penyuluhan ini, yang merupakan upaya untuk meningkatkan kesadaran dan pengetahuan akan stress pada siswa SMK 4 Garut, maka metode yang digunakan yaitu pembelajaran ceramah / lecture yang difasilitasi dengan media slide. Metode pembelajaran ceramah / lecture 
merupakan salah satu metode pembelajaran yang digunakan untuk melakukan penyuluhan pada kelompok besar atau dengan audience yang lebih dari 15 orang. Saat menggunakan metode ini, penceramah akan menyampaikan informasi dan pengetahuannya secara lisan namun saat ia memaparkan, ia dituntut untuk bisa membuat para audience tidak merasa bosan karena ceramah / lecture ini merupakan salah satu contoh metode pembelajaran yang bersifat pasif atau satu arah. Media yang digunakan dalam pendidikan kesehatan ini berupa PPT atau powerpoint. Media powerpoint dapat memudahkan audience untuk memahami materi karena hanya menampilkan poin - poin utama yang disajikan.

\section{HASIL DAN PEMBAHASAN}

Kegiatan pendidikan dan promosi kesehatan ini dilaksanakan pada hari Sabtu, 12 Desember 2020 pukul 09.00 s/d 11.30 WIB dengan menggunakan aplikasi Zoom Meeting. Sasaran pada kegiatan pendidikan dan promosi kesehatan ini adalah siswa SMKN 4 Garut. Sebelum tim melakukan penyebaran poster kepada siswa SMKN 4 Garut, tim terlebih dahulu memberikan surat permohonan izin yang disampaikan kepada pihak SMKN 4 Garut. Dari hasil penyebaran poster tersebut peserta diwajibkan untuk melakukan registrasi dan masuk ke dalam Whatsapp Group. Peserta yang hadir pada kegiatan pendidikan dan promosi kesehatan berjumlah 16 peserta.

Hasil kegiatan awal menunjukkan data karakteristik dari peserta Penkes terdiri atas jenis kelamin dan tingkat pendidikan. Untuk karakteristik peserta berdasarkan jenis kelaminnya didapatkan hasil, peserta berjenis kelamin lakilaki sebanyak 7 orang dan peserta berjenis kelamin perempuan sebanyak 9 orang. Selanjutnya, yaitu karakteristik peserta berdasarkan kelas, bahwa kelas 10 sebanyak satu orang, kelas 11 sebanyak 11 orang, dan peserta kelas 12 ialah sebanyak empat orang.

Berdasarkan hasil penerapan Teori Health Belief Model, didapatkan dari: Kerentanan yang dirasakan dengan menilai dan mengukur kerentanan tertularnya Covid-19 pada remaja sekolah khususnya SMKN 4 Garut yang disebabkan oleh faktor stress; Menilai dan mengukur adanya keparahan dari faktor stress pada remaja sekolah khsusnya SMKN 4 Garut dari banyaknya peserta yang masih belum memahami atau mendapatkan pengetahuan mengenai stress dan strategi untuk mengendalikan stress yang mereka rasakan selama Pandemi Covid-19 yang dapat dilihat dari masih banyaknya peserta yang menjawab salah, bahkan tidak menjawab dari pertanyaan yang kami berikan.

Menilai adanya manfaat yang diperoleh peserta penkes saat peserta yang mengisi formulir evaluasi kegiatan menyampaikan, bahwa materi yang kami berikan pada kegiatan penkes ini sangat bermanfaat dan menambah ilmu bagi para peserta, terutama dalam mengendalikan stress yang dialami para peserta selama pandemic Covid-19 ini; menilai adanya hambatan dari para peserta dalam mengendalikan stress mereka terutama selama pandemic covid-19 ini ialah berasal dari lingkungan, baik lingkungan keluarga, maupun lingkungan pertemanan mereka yang ami temukan pada beberapa pertanyaan peserta.

Cue to action Pada kegiatan penkes ini, kami menilai adanya stimulus dari para peserta untuk berkeinginan dapat mengendalikan stress yang mereka alami terutama selama pandemic covid-19 ini ditunjukkan dengan antusias peserta yang bertanya mengenai berbagai strategi yang sesuai dengan sumber stress atau stressor yang mereka hadapi; menilai adanya kemanjuran diri atau adanya rasa percaya diri atau kemampuan pada peserta dalam mengaplikasikan startegi pengendalian stress terutama selama masa pandemic covid-19 ini ialah dengan 
adanya peningkatan pada pemahaman dan pengetahuan peserta mengenai strest itu sendiri dan koping sebagai salah satu strategi dalam mengendalikan stress yang ditunjukkan dengan adanya peningkatan jumlah benar daripada saat pretest pada soal yang kami berikan kepada peserta mengenai stress dan strategi koping.

Peserta pendidikan dan promosi kesehatan berdasarkan jenis kelamin paling banyak ditemukan pada jenis kelamin perempuan. Jumlah perempuan 9 peserta ( $56.25 \%)$ sedangkan pada laki-laki 7 peserta $(43.75 \%)$, hal ini dikarenakan motivasi belajar pada perempuan lebih tinggi dari pada laki-laki yang sesuai dengan hasil penelitian lain yang menyebutkan bahwa siswa berjenis kelamin perempuan lebih tinggi motivasi belajarnya dibandingkan siswa berjenis kelamin laki-laki ( Putra M, 2018). Berdasarkan kategori kelas, peserta kelas 11 lebih banyak dibandingkan kelas 10 dan 12 . Jumlah kelas 10 sebanyak 1 peserta (6.25\%), kelas 11 sebanyak 11 peserta (68.75\%) dan kelas 12 sebanyak 4 peserta ( $25 \%$ ), hal ini dikarenakan setiap orang yang berada pada kelas tersebut mempunyai kesibukan yang berbeda beda.

Berdasarkan penilaian hasil pre-test diketahui tingkat pengetahuan dan kemampuan siswa dan siswi SMKN 4 Garut dalam melakukan pengelolaan stres sebelum diberikan edukasi sebagian besar berada dalam kategori cukup, dengan jumlah 15 responden (100\%) mampu menjawab benar < 5 soal. Hal ini sejalan dengan penelitian yang dilakukan oleh Arosna (2014) yang menyatakan bahwa tingkat pengetahuan mahasiswa sebelum diberikan pendidikan kesehatan mayoritas berada dalam kategori cukup yaitu sebanyak 19 mahasiswa dari 30 mahasiswa atau sebesar 63,3\%. Penyebab responden memiliki tingkat pengetahuan dalam kategori cukup dikarenakan banyak faktor yang mempengaruhi. Menurut Budiman dan Riyanto (2014) penerimaan informasi merupakan salah satu faktor yang mempengaruhi pengetahuan. Salah satu faktor yang mempengaruhi kurangnya pengetahuan responden adalah kurangnya informasi mengenai pengelolaan stres di lingkungan sekolah serta tidak didukung dengan kurikulum pelajaran Bimbingan Konseling yang membahas tentang stres dan pengelolaannya.

Berdasarkan hasil post-test, diketahui bahwa tingkat pengetahuan siswa dan siswi SMKN 4 Garut terhadap cara untuk mengelola stres setelah diberi edukasi mengalami peningkatan yang ditandai dengan pengurangan jumlah pertanyaan yang dijawab salah oleh para responden atau para peserta penkes. Ini disebabkan oleh peningkatan pengetahuan responden setelah diberi perlakuan yang sejalan dengan pendapat Djamarah (2000), bahwasannya pengetahuan seseorang dapat ditingkatkan dengan cara penyuluhan tanpa alat peraga (ceramah) maupun dengan alat peraga.

Evaluasi tingkat pengetahuan sebelum dan sesudah diberikan edukasi hasil pretest dan posttest menunjukkan bahwa rerata skor pengetahuan peserta sebelum dan sesudah penkes mengalami peningkatan. Setelah diberikan edukasi sebagian besar responden mampu menjawab soal yang sebelumnya 0 responden (0\%) menjawab benar < 5 soal menjadi 7 responden $(46,67 \%)$ menjawab benar > 5 soal. Hal ini menunjukkan bahwa adanya pengaruh pendidikan kesehatan yang diberikan mengenai strategi coping untuk mengatasi stres terhadap para peserta.

Evaluasi proses pendidikan dan promosi kesehatan yang berlangsung mengenai edukasi strategi koping sebagai upaya dalam menurunkan tingkat stress pada siswa SMK 4 Garut Selama Pandemi Covid-19, terdapat 16 peserta yang mengikuti rangkaian acara penkes tersebut. Peserta yang mengikuti kegiatan melalui Zoom Meeting sangat tertarik dengan apa yang disampaikan oleh pemateri. Kegiatan berjalan kondusif karena peserta memperhatikan dengan baik dan seksama terhadap apa yang dijelaskan oleh pemateri. Pada sesi 
Tahun [JURNAL KREATIVITAS PENGABDIAN KEPADA MASYARAKAT (PKM), P-ISSN:

2021 2615-0921 E-ISSN: 2622-6030 VOLUME 4 NOMOR 3 TAHUN 2021] HAL 564-572

tanya jawab peserta sangat antusias dalam mengajukan pertanyaan dan tingkat keingintahuannya juga sangat tinggi.

Gambar.1. Poto Kegiatan Edukasi Virtual
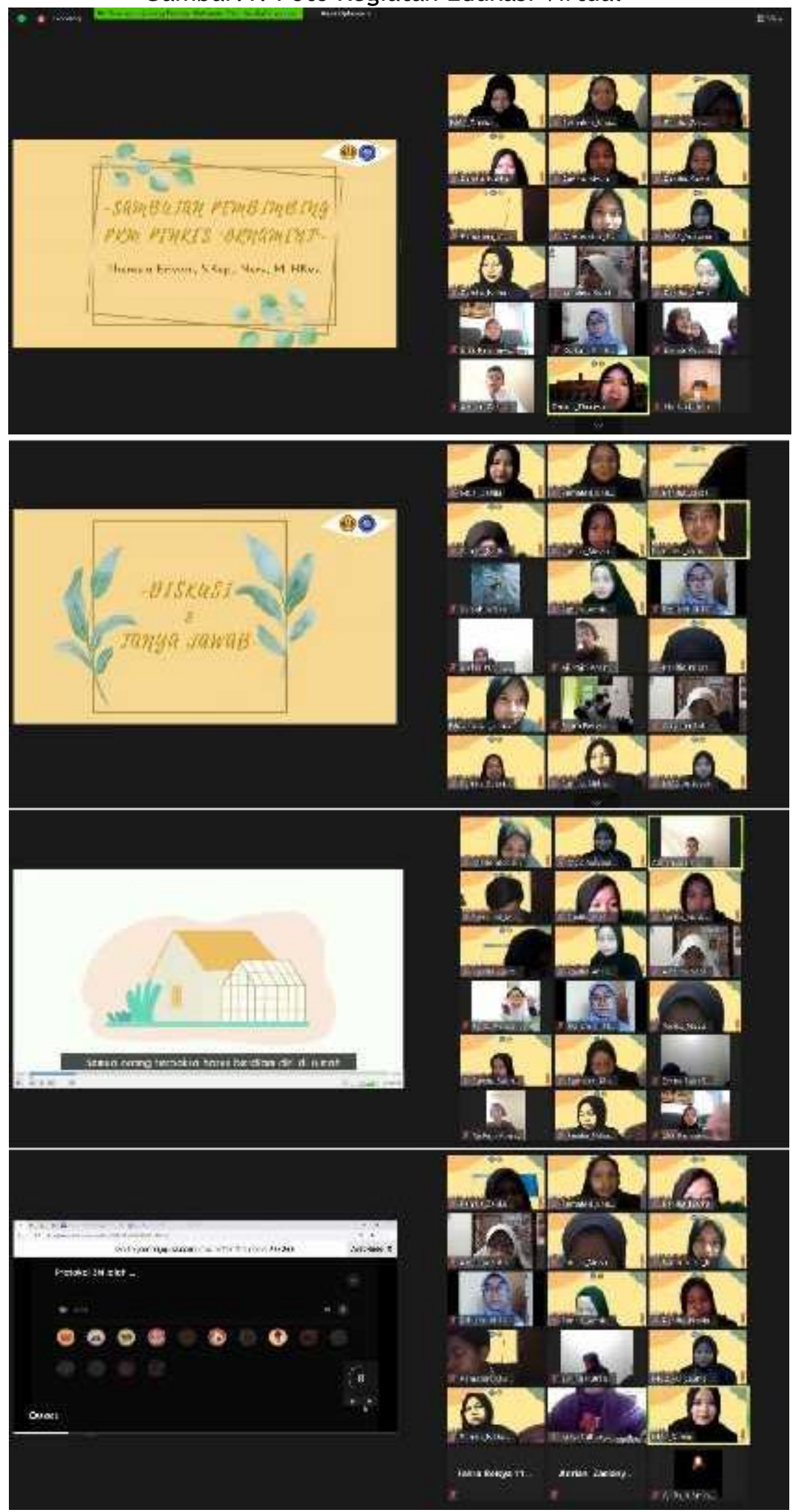


\section{KESIMPULAN}

Peserta pendidikan kesehatan berdasarkan jenis kelamin, mayoritas perempuan yang hadir dan berdasarkan kelas, untuk kelas 11 lebih banyak dari kelas lainnya. Pada saat dilakukan pretest hasil yang didapat yaitu peserta sebagian besar cukup memiliki tingkat pengetahuan tentang pengelolaan stress. Pada saat dilakukan postest, tingkat pengetahuan tentang cara mengelola stress mengalami peningkatan, hal ini dilihat pada pengurangan jumlah pertanyaan yang dijawab salah oleh responden serta perbedaan sebelum dan sesudah diberi edukasi mengalami peningkatan. Selama kegiatan pendidikan dan promosi kesehatan berlangsung, peserta mengikuti rangkaian acara dengan sangat antusias dan berjalan kondusif, namun disamping itu terdapat beberapa kendala seperti miskomunikasi di internal sekolah dan pada saat pelaksaan pretest maupun postest terdapat beberapa peserta yang tidak bisa mengisi karena satu dan lain hal.

Rencana berkelanjutan program dimasa yang akan datang adalah: Jumlah peserta dapat di follow up beberapa hari sebelum kegiatan berlangsung sehingga informasi mengenai kegiatan ini tersampaikan dan tersebar dengan baik, berkaitan dengan hal tersebut, untuk selanjutnya, perlu melibatkan langsung pihak sekolah dan organisasi di sekolah untuk mengkonfirmasi kegiatan pendidikan dan promosi kesehatan. Sehingga, dapat meminimalisir terjadinya miskomunikasi, baik pihak guru yang dihubungi maupun pihak organisasi siswa. Mempersiapkan berbagai rencana alternatif dalam menangani berbagai Kendala dan hal-hal yang diluar kendali selama proses kegiatan berlangsung, sehingga kegiatan dapat berlangsung sesuai dengan yang di harapkan.

\section{DAFTAR PUSTAKA}

Ahmad, K. (2012). Promosi Kesehatan Dengan Pendekatan Teori Perilaku, Media dan Aplikasinya (Untuk Mahasiswa dan Praktisi Kesehatan). Jakarta. Divisi Buku Perguruan Tinggi. PT Raja Grafindo Persada.

Ananda, S. S. D., \& Apsari, N. C. (2020). MENGATASI STRESS PADA REMAJA SAAT PANDEMI COVID-19 DENGAN TEKNIK SELF TALK. Prosiding Penelitian dan Pengabdian kepada Masyarakat, 7(2), 248-256.

Amna, Z. (2020). SEHAT MENTAL PADA MASA PANDEMI COVID-19. Ragam Cerita Pembelajaran Dari COVID-19, 33.

Chatterjee, I. (2019). Impact Of Behavior On Student Responses To Online Ethical Surveys.

Compas, B. E., Jaser, S. S., Dunbar, J. P., Watson, K. H., Bettis, A. H., Gruhn, M. A., \& Williams, E. K. (2014). Coping and emotion regulation from childhood to early adulthood: Points of convergence and divergence. Australian journal of psychology, 66(2), 71-81.

Fadilah, M., Pariyana, P., Ningsih, W. I. F., Berlin, O., Azlin, A. W., \& Syakurah, R. A. (2020). PENGARUH SEMINAR ONLINE TERHADAP PENGETAHUAN DALAM MENINGKATKAN IMUNITAS UNTUK MENGHADAPI COVID-19 DAN PERSEPSI MENGENAI NEW NORMAL PADA MASYARAKAT AWAM. J-KESMAS: Jurnal Kesehatan Masyarakat, 6(2), 134-149.

Fitria, L., \& Ifdil, I. (2020). Kecemasan remaja pada masa pandemi Covid19. Jurnal EDUCATIO: Jurnal Pendidikan Indonesia, 6(1), 1-4.

Fitriani, S. (2011). Promosi kesehatan.

Gaol, N. T. L. (2016). Teori stres: stimulus, respons, dan transaksional. Buletin psikologi, 24(1), 1-11. 
Lestari, S. M. P., Oktia, D., \& Sudiadnyani, N. P. (2016). HUBUNGAN ANTARA KEMANDIRIAN DAN PENYESUAIAN DIRI DENGAN STRES PADA MAHASISWA/I BARU ANGKATAN 2015 FAKULTAS KEDOKTERAN UMUM UNIVERSITAS MALAHAYATI YANG MERANTAU DI BANDAR LAMPUNG. Jurnal Medika Malahayati, 3(2), 65-70.

Lyon, B. L. (2000). Stress, coping, and health. Handbook of stress, coping and health: Implications for nursing research, theory, and practice, 323.

Machfoedz, I., \& Suryani, E. (2003). Pendidikan kesehatan bagian dari promosi kesehatan. Fitramaya.

Musradinur, M. (2016). Stres dan Cara Mengatasinya dalam Perspektif Psikologi. JURNAL EDUKASI: Jurnal Bimbingan Konseling, 2(2), 183200.

Nasut, N. B., \& Nasrun, N. (2020). PELATIHAN KOPING ADAPTIF UNTUK MENURUNKAN DAMPAK PSIKOLOGI VIRUS COVID-19 DI SD PLUS JABAL RAHMAH MULIA, JL. BALAI DESA NO. 16-27, SUNGGAL, KEC. MEDAN SUNGGAL, KOTA MEDAN. Jurnal Pengabdian Kepada Masyarakat, 26(4), 248-253.

RI, K. S. N. (2020). KEPRES Nomor 9 Tahun 2020 Tentang PERUBAHAN ATAS KEPUTUSAN PRESIDEN NOMOR 7 TAHUN 2020 TENTANG GUGUS TUGAS PERCEPATAN PENANGANAN CORONA VIRUS DISEASE 2019 (COVID-19).

Riyanto, A. (2013). Kapita selekta kuesioner pengetahuan dan sikap dalam penelitian kesehatan. Jakarta: Salemba Medika, 66-69.

Sari, W., Rifki, A. M., \& Karmila, M. (2020). Analisis Kebijakan Pendidikan Terkait Implementasi Pembelajaran Jarak Jauh Pada Masa Darurat Covid 19.

Shalahuddin, I., Rosidin, U., \& Purnama, D. (2021). Edukasi Pada Masyarakat Desa Mekarbakti Kecamatan Pamulihan Kabupaten Sumedang Tentang Pentingnya Upaya-Upaya Pencegahan Penularan Penyakit Covid19. JURNAL KREATIVITAS PENGABDIAN KEPADA MASYARAKAT (PKM), 4(1), 1-9.

Sugiyono, S. (2013). Metode penelitian kualitatif. Bandung: Alfabeta.

Suryaatmaja, D. J. C., \& Wulandari, I. S. M. (2020). Hubungan Tingkat Kecemasan Terhadap Sikap Remaja Akibat Pandemik Covid19. Malahayati Nursing Journal, 2(4), 820-829.

Susilowati, D. (2016). Promosi Kesehatan (Modul Bahan Ajar Cetak Keperawatan).

World Health Organization. (2020). Doing what matters in times of stress: an illustrated guide. 